\title{
Examining the Relationship of CEO Compensation, Duality of Managing Director, and Weakness of Internal Organizational Controls with Audit Fee
}

\author{
Ali Reza Ahmadi Simab ${ }^{1}$, Amir Shams Koloukhi ${ }^{1,2^{*}}$ \\ ${ }^{1}$ Department of Management, Torbat-e-Jam Branch, Islamic Azad University, Torbat-e-Jam, Iran \\ ${ }^{2}$ Young Researchers and Elite Club, Neyshabur Branch, Islamic Azad University, Neyshabur, Iran
}

Keywords:

CEO compensation,

Duality of managing director, Internal controls, Audit fee, Tehran Stock Exchange

\section{Received}

17 November 2017

Received in revised form 08 June 2018

Accepted

18 June 2018

Correspondence:

shams1122@gmail.com

\begin{abstract}
This study aims to examine the effect of CEO compensation, duality of managing director, and quality of internal organizational controls on audit fee. Audit fee is the written fee in the related financial statements; CEO compensation is extracted from the decisions in the public meeting session. Duality of managing director is simultaneous attribution of chief or vice presidency of CEO to one person obtained from CEO reports. To measure internal controls' quality, reference of the auditor in his report to the significant internal control weaknesses was the basis. Using systematic random sampling, 91 firms listed in Tehran Stock Exchange from 2013-2015 were selected. For hypothesis test, panel regression model and Hausman test were used to select from combined models, fixed and random effects. Results showed a positive and significant correlation between natural logarithm of CEO compensation and audit fee. There was no significant correlation between duality of managing director, weakness of internal controls, and audit fee.
\end{abstract}

(C)AIMI Journals

Growing spread of communities and globalization of economy requires meeting various information needs. Thus, all professions, especially auditors should try to move along with technology changes across community needs. In such an environment, users need different information such as financial information for making decisions. Financial statements are the most important source for financial information provision. But, the significant point here is the 
reliability of financial statements. For confirming the reliability of financial statements, auditors are recruited.

In fact, the role of auditors is to assess information quality for the users. Auditing financial statements are an important tool for making sure of the clarity of financial information in the firms. Thus, audit quality is important in audit and capital market realms. Auditors receive some fee based on the factors including firm size, complexity and volume of operations, and auditor type (Waresul Karim, 2010). Another factor affecting audit quality is paid fee to the auditors since by enhancing audit fee their attempts increase as well as the audit quality. Also, higher fee makes most auditors dependent on their clients economically and since auditors don't want to lose their benefits in the firm, they try to do their jobs with higher quality (Hoitash, Markelevich, \& Barragato, 2007).

When stockholders of a firm deliver decision-making to the CEOs, the management has incentives to maximize his expected benefits even if these activities are not to the benefits of stockholders. Earnings management occurs when managers make changes by judgement about financial reporting and exchanges' structure in order to distract some stakeholders about corporate performance or affect the results of the contracts which depend on accounting digits (Rao \& Dandale, 2008). In fact, earnings management is an active attempt with the aim of pretending earnings to seem natural in order to reach a desirable level. In this regard, some incentives affecting stock price can include CEO payment, bonus increase, and preventing from loan contracts' breach. Most of these incentives relate to the future benefits such as rewards (Doupnik, 2008). CEO compensation can encourage them to manage earnings and increase audit risk. Audit risk influences audit fee. Prior studies showed that CEO compensation affects manipulating financial statement's assessments by the management (Bergstresser \& Philippon, 2006; Efendi, Srivastava, \& Swanson, 2007; Jayaraman \& Milbourn, 2014; Larcker, Richardson, \& Tuna, 2007). In this respect, some studies have used audit fee to show that CEO compensation affects auditors' perception about existing risk (Billings, Gao, \& Jia, 2013; Chen, Gul, Veeraraghavan, \& Zolotoy, 2003, Kannan, Skantz, \& Higgs, 2014; Kim, Li, \& Li, 2015).

Duality of managing director refers to the status in which a managing director has a role in CEO as a chief or vice president simultaneously. In fact, in such a firm, the supervisory role of managing director weakens after appointment as the head or vice president of CEO, leading these managers to think of maximizing their own benefits. Since based on the agency theory, there is a conflict of interests between stockholders (owners) and managers (agents), stockholders need financial information with high confidence level for financial decision makings. In fact, the role of the auditor is to evaluate information quality for the users. Also, auditing financial statements is an important tool for making sure about the clarity of corporate financial information. Thus, audit quality is important in auditing and capital market areas. Internal controls at corporate level refer to evaluating the reliability of corporate financial reports and the trends of reaching strategic goals, corporate operations, and the ability of considering corporate rules and laws. Internal control is an important part of managing an organization including plans, methods, and used organizational trends in reaching different 
missions and goals $\left({ }^{1} \mathrm{GAO}\right)$. Internal control is important from the view of independent auditors; since the limits, type, and administration of internal controls are effective in identifying audit methods and the volume of audit tasks; then, an independent auditor can make decisions after examining internal controls about the spread of examinations for commending about financial reports. This study investigates the effect of CEO compensation, duality of managing director, and quality of internal controls on audit fee and other effective factors used as controls.

\section{Review of the Literature}

Some studies suggest that CEOs' compensations can encourage them to manage earnings. Thus, they studied the effect of CEO compensation on earnings management. They showed that there is a correlation between CEO compensation and manipulation of financial statements (Burns \& Kedia, 2006; Cheng \& Warfield, 2005; Denis, Hanouna, \& Sarin, 2006; Efendi et al., 2007; Harris \& Bromiley, 2007; Jayaraman \& Melborn, 2014; Johnson, Ryan, \& Tian, 2009; Larcker et al., 2007; O'Connor, Priem, Coombs, \& Gilley, 2006). Few studies have found no evidences in this regard (Armstrong, Jagolinzer, \& Larcker, 2010; Baber, Kang, Liang, \& Zhu, 2009; Erickson, Hanlon, \& Maydew, 2006). Gul et al. (2003) investigated the effect of paid reward on accruals. Results showed that by increasing paid reward to CEOs, their motivation for manipulating accruals or earnings increases, leading to the audits with higher quality and higher fees. Firms with higher audit fees (which indicate more demands for supervising financial reports by the experts) have paid higher payments and rewards to the audit committee (Engel, Hayes, \& Wang, 2010). Studying ownership and quality of the audit, Ashbaugh \& Warfield (2003) concluded that using more qualitative auditors decreases when the corporate stocks are delivered to the stockholders with higher ownership percentages.

Bedard and Johnstone (2004) found that by increasing compensations to CEOs based on the margin of corporate profits, the likelihood of earnings management increases and auditors ask for higher fees for high quality audits and discovering manipulations. Wysocki (2010) examined if CEO rewards affect auditors' perceptions of audit risk. He found a positive correlation of CEO rewards and audit fee. Billings et al. (2013) studied ownership incentive of managing director and audit fee and found a positive correlation of them. But, they found no evidences of the correlation of ownership incentives of CEOs and audit fee. They found the effect of ownership incentive of managing director on the audit fee in the firms with higher internal controls over financial reporting. Kannan et al. (2014) concluded a positive correlation between the ownership incentive of both managing director and CEO of Vega Company with audit fee. But, no correlation was found between ownership incentive of managing director and CEO of Delta Company with audit fee. Kim et al. (2015) reported a correlation between the ownership incentive of the managing director and audit fee in their studied firms. But, no relationship was found between it and CEO compensation. They concluded that there is a correlation between the incentives of the managing director of Vega Company with its audit fee. But, no correlation was found between the incentives of managing director of Delta Company and CEO compensation of Vega and Delta companies and audit fee. Chen et al. (2015) found evidences on the positive correlation of ownership incentive of managing director

\footnotetext{
1 "Standards for Internal Control in the Federal Government", United States General Accounting Office (GAO)
} 
of Vega and audit fee, precisely after Sarbanes-Oxley Act (2002) requirements. They concluded more significant correlation of CEO compensation and audit fee for the firms facing more lawsuits. Harris \& Bromiley (2007) and Reason (2010) conducted studies on the role of $\mathrm{CEO}$ in identifying audit fee. Reviewing professional literature in this regard, they found that regarding the penetration of CEOs in changing auditor, CEOs affect audit fee. Based on these studies and the importance of the role of managers, we hypothesized a relationship between CEO compensation and audit fee. In this regard, the following hypothesis was stated:

$\mathbf{H}_{1}$ : There is a positive correlation between CEO compensation and audit fee.

Bedard and Johnstone (2004) examined assessment of auditors from earnings management risk by the management of business unit and the risks of corporate governorship weakness. They showed that how auditors plan and determine audit fee at the presence of these risks. For this study, the partners were evaluated whose employers worked in public accounting section. Results showed that auditors consider planned hours and higher fee for the employers who face the risk of earnings management. They showed a direct correlation for the above-mentioned variables. Also, for the firms with weaker governorship, they found a positive correlation between the risk of earnings management, planned hours, and audit fee. These findings provided evidences of the situation where auditors face a manipulating manager and a weak corporate governorship.

Desender, Aguilera, Crespi-Cladera, \& Garcia-Cestona (2011) examined the relationship of corporate governorship features and audit fee, concluding that audit service and independence of CEO complement each other when the ownership is decentralized. This implies that centralized ownership and CEO combination are good substitutes in supervising management. They concluded a correlation between CEO combination (independence and duality of managing dire) and audit fee.

Kim et al. (2015) examined the ownership incentive of managing director and audit fee to see if the former affects the latter. Prior studies show that the ownership of managing director increases executive managers' incentives in manipulating earnings for gaining more personal and financial earnings. If the auditor observes the ownership incentives of managing director in relation to the huge earnings, he combines manipulation risk and other risks in decisionmakings about fee. They expected a positive correlation of ownership incentives of managing director and audit fee. Their results agreed with their prediction. They showed that stock purchase discretion of managing director is positively correlated with audit fee after controlling abnormal accruals and other determinants of audit fee. Besides, they showed that the positive correlation of donating stock purchase discretion of managing director and audit fee decreases for the firms with more efficient corporate governorship.

Lesage and Ali (2011) examined the relationship of controlling stockholders' type and audit fee. They divided controlling stockholders into institutional, public, and family types. They found no significant correlation between family ownership and audit fee. But, they observed a significant and positive correlation between institutional and public ownership and audit fee. Ali and Lesage (2013) studied stockholders' ownership structure and audit fee among French firms. They showed a negative and significant correlation of public stockholders and audit fee 
and a significant and positive correlation between institutional stockholders and audit fee. Considering above studies and obtained results from them on the importance and effect of governorship structure on the audit fee, this study examines the relationship of duality of managing director and audit fee through the following hypothesis:

$\mathbf{H}_{2}$ : There is a significant correlation between duality of managing director and audit fee.

Ogneva and Subramanyam (2007) found primary evidences on the correlation of the weaknesses of internal controls and capital expenditure of the firms. They compared capital expenditure of the firms which reported the weaknesses of internal controls with capital expenditure of the firms which didn't report them. They also found a final increase in the capital expenditure of the firms which disclosed system weaknesses and the firms with no disclosure in this regard. Studies showed evidence implying that the weaknesses of internal controls increase uncertainty of the information in the market.

Hammersley, Myers, and Shakespeare (2008) conducted a study titled "weaknesses of internal controls and capital expenditure based on the evidences from Article 404 of SarbanesOxley". Findings showed a positive correlation between the weaknesses of internal controls with the capital expenditure of the firms. The weaker the internal controls, the higher the capital expenditure of the stockholders' equity.

In a study titled "internal controls, corporate risk management and performance", Smith (2007) examined the relationship of internal controls and corporate performance of the firms from one hand and the relationship of internal controls and risk management on the other hand. They showed that firms with weak internal controls have lower market value. They found that the more the weakness of disclosed internal controls, the lower the market value of the firm.

Zhang, Zhou, and Zhou. (2007) examined if there is a correlation between the quality of internal controls and evaluations of auditors and their comments on continuing corporate activities regarding the requirements of Sarbanes-Oxley Act of 2002. This study examined firms from 2004-2005 with weaker financial ability and structure which had disclosed the reports of internal controls. Results showed that the firms with weaker internal controls and significant weaknesses need more auditors' comments and their evaluations on continuing corporate activities. Analyses showed a positive and significant correlation between disclosing significant weaknesses and auditors' intent to disclose reports on continuing activities of the firms which disclosed significant weaknesses at corporate level.

Concerning conducted studies and the point that internal controls and their assessment from the view of auditors is important for future planning, this study states the following hypothesis:

$\mathbf{H}_{3}$ : There is a positive correlation between the weakness of internal controls and audit fee.

\section{Sample}

The population of this study included all listed firms in Tehran Stock Exchange from all industries since 2014-2015. To select the sample, systematic random sampling was used. Firms with the following conditions were selected as the sample: 
1. Firms belonging to financial intermediaries, holding and banks were excluded from the sample.

2. Transactions of the firms didn't stop during study period.

3. Firms were accepted in Tehran Stock Exchange since early 2012.

4. All data of the firms for conducting this study were available.

Regarding above conditions, 91 firms were selected.

\section{Methodology}

This study examined the effect of CEO compensation, duality of managing director, and quality of internal controls on the audit fee, using regression method of Bryan and Mason (2016) as follows:

$$
\begin{aligned}
& \text { LNAF }=\beta_{0}+\beta_{1} \text { LNCom }+\beta_{2} \text { CEO Dual }+\beta_{3} \text { In-Con } \mathrm{W}+\beta_{4} \text { LNSize }+\beta_{5} \text { RECTA }+\beta_{6} \text { INVTA } \\
&+ \beta_{7} \text { CASH_FLOW }+\beta_{8} \text { SPFIRM }+\beta_{9} \text { LOSS }+\beta_{10} \text { LEVERAGE }+\beta_{11} \text { LIQ }+\beta_{12} \text { ROA }+ \\
& \beta_{13} \text { RESIDENCE }+\beta_{14} \text { BIG }+\beta_{15} \text { FIRMTENURE }+\beta_{16} \text { REPORTLAG }+\beta_{17} \text { IIndustry }+ \\
& \beta_{18} \text { } \text { EYear }+\varepsilon
\end{aligned}
$$

Where,

$L N A F$ is obtained from the written sum of the financial statements of the firms. Thus, the sample's member firms should be the ones whose audit fees are disclosed in the financial statements. LNCom is the natural logarithm of paid compensation to CEO in the studied years. CEO Dual is a dummy variable which takes the value of 1 if the directing manager has the positions of the head and vice presidency of the company simultaneously, otherwise it is 0 . InCon $W$ can be extracted from the audit report of previous year, taking the value of 1 if the auditor has explored a significant weakness in the internal controls in the report of previous year, otherwise it is 0. Ln SIZE is the natural logarithm of average asset and sale. RECTA is the ratio of claims to total assets. IN VTA is the ratio of inventory to total assets. CASH_FLOW is the ratio of operating cash flow to total assets. LOSS is used to identify the corporate position; if the company bears loss and discloses it, it takes the value of 1 , otherwise it is 0. LEVERAGE results from dividing total debts into total assets and is used as a financial leverage for identifying the company power for paying debts. $A R \_I N V$ results from the sum of current assets except for cash (receivables and inventory) divided into total assets, indicating operating risk. $L I Q$ is the ratio of current assets to current debts. $D A$ is the ratio of total debts to total assets. $R O A$ is the ratio of net earnings to total assets. BIG takes the value of 1 if the firm is audited by audit firm or the institutes ranking A in registered accountants' committee, otherwise it is 0 . SPFIRM takes the value of 1 if the audit firm is expert in an industry, otherwise it is 0 . FIRMTENURE is the number of tenure years of the auditor. Inflation refers to the inflation rate announced by the central bank. FOREIGN takes the value of 1 if the firm has foreign transactions, otherwise it is 0 . AGE shows the number of the presence of the firm in Tehran Stock Exchange. Industry identifies the type of the industry in which the firm operates. 


\section{Results}

Parameters of the study model are reflected in Table 2.

Table 2

Results of Fitness Good Related to Testing Research Hypothesis

\begin{tabular}{|c|c|c|c|c|c|}
\hline$p$ & $t$ & Std. Error & Coefficient & & Variable \\
\hline .000 & 7.23 & .30 & 2.24 & & $\alpha_{0}$ \\
\hline .0001 & 3.98 & .009 & .03 & & LnCom \\
\hline .13 & 1.49 & .05 & .07 & & EO Dual \\
\hline .88 & -.14 & .03 & -.005 & & COW \\
\hline .001 & 15.64 & 2.01 & .30 & & LNSIZE \\
\hline .003 & -2.96 & .11 & -.35 & & RECTA \\
\hline .53 & -.62 & .17 & -.10 & & INVTA \\
\hline .21 & -1.25 & .16 & -.20 & & $\mathrm{CFO}$ \\
\hline .97 & -.02 & .07 & -.002 & & LOSS \\
\hline .10 & -1.68 & .08 & -.14 & & LEV \\
\hline .06 & -1.84 & .03 & -.05 & & LIQ \\
\hline .002 & -3.19 & .21 & -.67 & & ROA \\
\hline .10 & 1.62 & .04 & .07 & & BIG \\
\hline .001 & 4.83 & .04 & .21 & & udit-Exp \\
\hline .001 & 9.30 & .007 & .06 & & ENURE \\
\hline .005 & 2.81 & .0006 & .002 & & PORRLAG \\
\hline .003 & 2.91 & .04 & .12 & & ESIDEN \\
\hline \multicolumn{2}{|c|}{91.59} & \multicolumn{2}{|c|}{$F$} & .86 & R-squared \\
\hline \multicolumn{2}{|c|}{.001} & \multicolumn{2}{|c|}{$p$ (F-Statistic) } & .85 & Adjusted R-squared \\
\hline
\end{tabular}

As presented in Table 2, since $t$ value is significant and concerning regression coefficient of each variable, it is concluded that the variables of natural logarithm of CEO compensation, firm size, industrial expertise of the auditor, tenure of the auditor, days between fiscal year and the date of audit report and the location of audit institute have a positive and significant correlation with audit fee. However, the ratio of claims to the assets has a negative and significant correlation with audit fee. Concerning the positive and significant correlation of natural logarithm of managers' reward and audit fee of the firms, $\mathrm{H}_{1}$ is accepted. Whereas, for the lack of a significant correlation between duality role of managing director, weakness of internal controls, and audit fee, $\mathrm{H}_{2}$ and $\mathrm{H}_{3}$ are rejected.

Also, $F$ value and its likelihood are 91.59 and .001 , indicating the significance of the whole model. Modified determination coefficient of the model was .85 , indicating that over $85 \%$ of the dependent variable is explained by the explanatory variables.

\section{Conclusion}

This study examined the effect of CEO compensation, duality of managing director, and quality of internal organizational controls on audit fee. Three hypotheses were stated in this regard. About $\mathrm{H}_{1}$, based on the regression model of Bryan and Mason (2016), a positive and significant correlation was found between CEO compensation and audit fee. This result agrees 
with that of Gul et al. (2003) and Engel et al. (2010), Bedard and Johnstone (2004), and Wysocki (2010), showing a positive and significant correlation between CEO compensation and audit fee. On the other hand, a positive and significant correlation of CEO compensation and audit fee disagrees with the results of Armstrong et al. (2010), Baber et al. (2009), Erickson et al. (2006) who found that there is no significant correlation between exclusive audit market and audit fee. About the second hypothesis on the relation of duality of managing director and audit fee based on regression model of Bryan and Mason (2016), no significant correlation was found despite a positive correlation of these two variables. Also, Boo and sharma (2008) did not find a significant correlation between duality of managing director and audit fee. On the other hand, this finding conflicts with that of Desender et al. (2011) who found a significant correlation between them. This positive correlation agrees with the results of Kim et al. (2015) but conflicts with them regarding its significance.

About the third hypothesis implying the correlation of weak internal controls and audit fee, based on the regression model of Bryan and Mason (2016), this study showed a negative correlation of them without any significance. It must be mentioned that no study has directly examined the relationship of these two variables. Thus, this result cannot be compared with other studies.

\section{References}

Ali, C. B., \& Lesage, C. (2013). Auditing pricing and nature of controlling shareholders: Evidence from France. China journal of accounting Research, 6(1), 21-34.

Armstrong, C. S., Jagolinzer, A. D., \& Larcker, D. F. (2010). Chief executive officer equity incentives and accounting irregularities. Journal of Accounting Research, 48(2), 225-271.

Ashbaugh, H., \& Warfield, T. D. (2003). Audits as a corporate governance mechanism: Evidence from the German market. Journal of International Accounting Research, 2(1), 1-21.

Baber, W., Kang, S., Liang, L., \& Zhu, Z. (2009). Shareholder rights, corporate governance and accounting restatement. SSRN Electronic Journal. doi: 10.2139/ssrn.760324

Bedard, J. C., \& Johnstone, K. M. (2004). Earnings manipulation risk, corporate governance risk, and auditors' planning and pricing decisions. The Accounting Review, 79(2), 277-304.

Bergstresser, D., \& Philippon, T. (2006). CEO incentives and earnings management. Journal of financial economics, 80(3), 511-529.

Billings, B. A., Gao, X., \& Jia, Y. (2013). CEO and CFO equity incentives and the pricing of audit services. Auditing: A Journal of Practice \& Theory, 33(2), 1-25.

Boo, E. F., \& Sharma, D. (2008). The association between corporate governance and audit fee of bank holding companies. Corporate governance. 8(4), 28-45.

Bryan, D. B., \& Mason, T. W. (2016). Extreme CEO pay cuts and audit fees. Advances in Accounting, 33, 1-10.

Burns, N., \& Kedia, S. (2006). The impact of performance-based compensation on misreporting. Journal of financial economics, 79(1), 35-67.

Chen, Y., Gul, F. A., Veeraraghavan, M., \& Zolotoy, L. (2015). Executive equity risk-taking incentives and audit pricing. The Accounting Review, 90(6), 2205-2234.

Cheng, Q., \& Warfield, T. D. (2005). Equity incentives and earnings management. The accounting review, 80(2), 441-476.

Denis, D. J., Hanouna, P., \& Sarin, A. (2006). Is there a dark side to incentive compensation? Journal of Corporate Finance, 12(3), 467-488.

Desender, K., Aguilera, R. V., Crespi-Cladera, R., \& Garcia-Cestona, M. A. (2011). Board characteristics and audit fees: When does ownership matter. Working Paper. University of Illinois, IL.

Doupnik, T. S. (2008). Influence of culture on earnings management: A note. Abacus, 44(3), 317-340. 
Efendi, J., Srivastava, A., \& Swanson, E. P. (2007). Why do corporate managers misstate financial statements? The role of option compensation and other factors. Journal of Financial Economics, 85(3), 667-708.

Engel, E., Hayes, R. M., \& Wang, X. (2010). Audit committee compensation and the demand for monitoring of the financial reporting process. Journal of Accounting and Economics, 49(1), 136-154.

Erickson, M., Hanlon, M., \& Maydew, E. L. (2006). Is there a link between executive equity incentives and accounting fraud? Journal of Accounting Research, 44(1), 113-143.

Gul, F. A., Chen, C. J., \& Tsui, J. S. (2003). Discretionary accounting accruals, managers' incentives, and audit fees. Contemporary Accounting Research, 20(3), 441-464.

Hammersley, J. S., Myers, L. A., \& Shakespeare, C. (2008). Market reactions to the disclosure of internal control weaknesses and to the characteristics of those weaknesses under Section 302 of the Sarbanes Oxley Act of 2002. Review of Accounting Studies, 13(1), 141-165.

Harris, J., \& Bromiley, P. (2007). Incentives to cheat: The influence of executive compensation and firm performance on financial misrepresentation. Organization Science, 18(3), 350-367.

Hoitash, R., Markelevich, A., \& Barragato, C. A. (2007). Auditor fees and audit quality. Managerial Auditing Journal, 22(8), 761-786.

Jayaraman, S., \& Milbourn, T. (2014). CEO equity incentives and financial misreporting: The role of auditor expertise. The Accounting Review, 90(1), 321-350.

Johnson, S. A., Ryan, H. E., \& Tian, Y. S. (2009). Managerial incentives and corporate fraud: The sources of incentives matter. Review of Finance, 13(1), 115-145.

Kannan, Y. H., Skantz, T. R., \& Higgs, J. L. (2014). The impact of CEO and CFO equity incentives on audit scope and perceived risks as revealed through audit fees. Auditing: A Journal of Practice and Theory, 33(2), 111-139.

Kim, Y., Li, H., \& Li, S. (2015). CEO equity incentives and audit fees. Contemporary Accounting Research, 32(2), 608-638.

Larcker, D. F., Richardson, S. A., \& Tuna, I. (2007). Corporate governance, accounting outcomes, and organizational performance. The Accounting Review, 82(4), 963-1008.

Lesage, C., \& Ali, C. B. (2011). Ownership concentration and audit fees: Do auditors matter most when investors are protected least? Paper presented at the Crises et Nouvelles Problématiques de la Valeur, Nice, France. Abstract retrieved from https://hal.archives-ouvertes.fr/hal-00476923

O'Connor, J. P., Priem, R. L., Coombs, J. E., \& Gilley, K. M. (2006). Do CEO stock options prevent or promote fraudulent financial reporting? Academy of Management Journal, 49(3), 483-500.

Ogneva, M., Subramanyam, K. R., \& Raghunandan, K. (2007). Internal control weakness and cost of equity: Evidence from SOX Section 404 disclosures. The Accounting Review, 82(5), 1255-1297.

Rao, N., \& Dandale, S. (2008). Earnings management: A study of equity rights issues in India. The ICFAI Journal of Applied Finance, 14(11), 20-34.

Reason, T. (2010). Auditing your auditor. CFO Magazine, (April). Retrieved from http://ww2.cfo.com/accountingtax/2010/04/auditing-your-auditor/

Sarbanes, P. (2002, July). Sarbanes-oxley act of 2002. In The Public Company Accounting Reform and Investor Protection Act. Washington DC: US Congress.

Smith, G. (2007). Greatest IT audit and security risks of 2006. Journal of Corporate Accounting \& Finance, 18(4), 43-48.

Waresul Karim, A. K. M. (2010). Audit Pricing, Audit Concentration, and Big-4 Premium in Bangladesh. Paper presented at the 18th Asian Pacific Conference on International Accounting Issues, Maui, Hawaii, USA.

Wysocki, P. (2010). Corporate compensation policies and audit fees. Journal of Accounting and Economics, 49(1), $155-160$.

Zhang, Y., Zhou, J., \& Zhou, N. (2007). Audit committee quality, auditor independence, and internal control weaknesses. Journal of accounting and public policy, 26(3), 300-327. 